Marian Żukowski, Helena Żukowska

\title{
TAX REFORMS IN RUSSIA
}

\section{Prerequisites for reforms of the tax system in Russia after 1990}

Russia is a state to be reckoned with economically and politically in the world. It has multiple ties with the world's economy. Many countries are interested in economic cooperation with Russia as a strategic supplier of natural resources and energy carriers. Furthermore, Russia is an important and ready market for consumer goods and investment goods.

At the end of the 1980s and the beginning of the 1990s Russia launched economic reforms of the market character. The scale of deformation of the Russian economy after the Communist period was so large that despite the objective conditions which made the reforms inevitable, the process of change encountered many obstacles. They emerged among originators and executors of reforms, the society, and in the economic system under reform, with its deep-rooted bureaucracy. After years of functioning in the Communist system, the society, on the one hand, expected market reforms to bring many favourable changes, but on the other hand had serious and, as it turned out, justified fears for the future of the economy and for its own well-being. If we add to these the reluctance and resistance of bureaucracy, it is no wonder that the reform process in Russia has not been easy. 
Figure 1. The structure of tax yield of the consolidated budget

of the Russian Federation in 19991

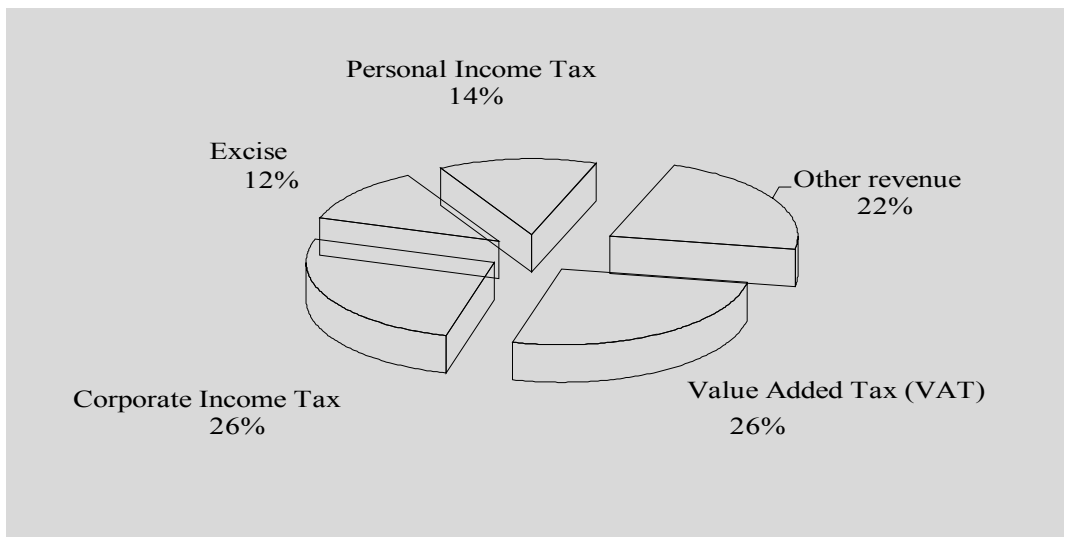

Source: M. Żukowski, H. Żukowska, Reforma systemu podatkowego w Federacji Rosyjskiej, [in:] „Polski system podatkowy. Zatożenia i praktyka”. The publishing house of Maria Curie-Sktodowska University, Lublin 2004, pp. 536-543.

The public finance sector was an important area of the economic system reform in Russia after 1990. The persistent deficit of the federal budget led to an increase in the internal and external debt of the state. The Russian government adopted the simplest method of financing the budget deficit: it issued more and more treasuries (mainly short-term bonds). Even though those securities were popular among domestic and foreign entities owing to their high profitability, the demand for them collapsed at the beginning of 1998. According to international ratings agencies, treasuries issued by the Russian government were burdened with an increasing risk. Simultaneously, costs of the internal debt servicing were progressively growing. The ratings for Russia were falling, and at the same time several financial crises occurred on emerging markets in Asia, Argentina and Mexico. Foreign investors were losing confidence in Russian securities, and as a result many of them decided to sell their securities and withdraw from the Russian market. Further issues of state bonds were increasingly difficult to sell. In the middle of 1998 there was a collapse of the currency market, the securities market and the interbank market. Internal and external insolvency was officially declared and restrictions on currency operations for residents were introduced. A 90-day moratorium on the purchase of Russian public debt obligations was announced. The 1998 crisis, affecting the whole banking system and the economy, brought about numerous and extensive negative consequences for the economy and the society. The real earnings of the society were

1 The reform of the tax system in Russia: logic and expected results (30 June 2000), the Bureau of Economic Analysis BEA, www.beafnd.org/russian/activity/library/sprav.htm, p. 4. 
going down, the budget deficit was increasing, and inflation was soaring. Depositors were withdrawing their deposits from bank accounts in panic. In consequence, many banks lost their liquidity and suspended payment of deposits.

The slump gave rise to another recession wave in the Russian economy. Nevertheless, the crisis became also a kind of a turning point in economic changes: it made the acceleration of reforms necessary and led to decisions which later proved to be conducive to the quicker transformation and reconstruction of the economy after the slump. It also partly contributed to the fundamental reform of the tax system.

The tax system of the Russian Federation, similarly as the whole economic system after 1990, demanded radical reforms, whose main objectives were: to create favourable conditions for effective performance of enterprises and investors (also from abroad), to ensure due collection of taxes, as well as to bring the tax system in Russia closer to solutions adopted in developed states. ${ }^{2}$ Experts described the tax system in Russia before the reforms as highly complicated, too expanded, and marked by a high level of the state fiscalism. The right of the regional and local authorities to levy taxes was frequently misused and, in consequence, the number of mandatory taxes and charges in the Russian Federation increased from 41 at the beginning of the 1990s to about 200 in 1996. Further weaknesses of the tax system, proving the need for reforms, were: low efficiency of tax authorities, leakiness of the tax system, and a large-scale informal economy. The inefficiency of the tax system in Russia is clearly illustrated by the examples below. The tax liabilities of several major Russian companies from the sector of producers and exporters of oil and gas, compared to the level of their discharge, were as follows in July 1998: ${ }^{3}$

- Lukoil paid to the budget 24.3 million out of due 672 million USD (3.6\%),

- Sidanko discharged only 2.2 million out of due 740 million USD $(0.3 \%)$,

- ONAKO paid only 0.5 million USD out of due 215 million USD ( $0.23 \%)$,

- Sławnieft discharged 3.8 million USD out of due 341 million USD (9.3\%).

In 2000 the government of the Russian Federation decided to undertake the tax system reform. The following goals of the reform were planned: ${ }^{4}$ simplifying the tax system, restricting the scope of the informal economy, improving the performance of tax administration, reducing direct tax rates, and relieving tax burdens. As part of the tax system reform, the following measures were suggested:

2 More in: M. Żukowski, H. Żukowska, Reforma systemu podatkowego w Federacji Rosyjskiej, [in:] „Polski system podatkowy. Założenia i praktyka”. The publishing house of Maria Curie-Skłodowska University, Lublin 2004, pp. 536-543.

3 L. Makarewicz, Kryzys postsowieckoj bankowskoj sistiemy. Moscow 1999, pp. 45 - 47.

4 The reform of the tax system in Russia: logic and expected results (30 June 2000), the Bureau of Economic Analysis BEA, www.beafnd.org/russian/activity/library/sprav.htm 
1. adopting a single rate of personal income tax and excluding expenditure on healthcare and education from the tax base,

2. transforming many different elements of the social insurance contribution into a single unified social tax dependent on income,

3. changing the rules of determining the tax base for enterprises,

4. raising excise rates on oil-based products, alcoholic beverages and tobacco,

5. reform of turnover tax,

6. abolishing some VAT deductions and paying the entire VAT to the federal budget,

7. replacing real estate tax with property tax and land tax (cadastral tax),

8. introducing regional road tax which would replace the tax on owners of transport means and taxes on particular forms of transport.

The reform of the tax system in Russia aimed at introducing the basic tax rules: universality, equality, clarity, freedom of establishment, non-transferability, and nonretroactivity. It was decided that amendments to the tax law provisions should come into force on 1 January of the year following their passage, but not earlier than one month after the date of publication. Moreover, the idea emerged in the reform plans that all ambiguities and doubts shall be settled to the benefit of the taxpayer. ${ }^{5}$

\section{Russian tax system after 2000}

The basic legal act governing the tax system in the Russian Federation after 2000 is the Tax Code, which consists of two parts. Part I of the Tax Code, which became effective on 1 January 1999, defined the basic taxation rules, described in detail the procedures to be followed by the tax service, and determined rules of liability for infringing tax laws. On 1 January 2001, additional four sections reforming VAT, excise, personal income tax, and unified social tax (the way of calculation of social insurance contributions) ${ }^{6}$ were introduced by Part II of the Tax Code. Corporate income taxes, goods and services tax, and natural resources tax have been in force since 1 January 2002, and transport tax since 31 August 2002. A positive tendency in the Russian tax legislation is a growing recognition of international regulations. 
Tax Reforms in Russia

Table 1. Major changes in PIT, CIT and VAT in the Russian Federation

\begin{tabular}{|c|c|c|}
\hline PIT & CIT & VAT \\
\hline 1992: 3 rates 12, 20,30\% & $\begin{array}{c}\text { 1992: standard rate 32\% } \\
\text { and other rates depending on } \\
\text { sector }\end{array}$ & $\begin{array}{c}\text { 1992: VAT with 28\% rate, } \\
\text { lower rates for food products }\end{array}$ \\
\hline $\begin{array}{c}\text { 2001: flat rate of 13\% } \\
\text { and abolition of many deductions }\end{array}$ & $\begin{array}{c}\text { 1994: to 37\%, then reduced } \\
\text { to 30\% }\end{array}$ & $\begin{array}{c}\text { 1993: standard rate reduced } \\
\text { to 20\%, reduced rate } 10 \%, \\
\text { numerous exemptions }\end{array}$ \\
\hline & $\begin{array}{c}\text { 2002: rate reduced to 24\%, } \\
\text { deductions and exemptions } \\
\text { abolished }\end{array}$ & $\begin{array}{c}\text { 1994: additional turnover tax } \\
\text { of 3\% }\end{array}$ \\
\hline & & 2001: reduction of exemptions \\
\hline
\end{tabular}

Source: M.H. Grabowski, Reform of Tax System In Transition Countries, Transition Studies Review, Springer-Verlag 2005, No. 12 (2), pp. 293-213.

After 2000 in Russia the three-tier tax system was established, ${ }^{7}$ consisting of: federal taxes and charges, regional taxes, and local taxes. They all function on the basis of the federal legislation, but as regards the latter two categories of taxes, the regional and local governments are entitled to determine their rates and relevant procedures. There is a binding rule that the authorities of a lower tier cannot permit deductions in taxes of a higher category, even though a considerable part of revenue generated by these taxes goes to regional and local budgets, similarly as with the profits tax. The regional authorities can only permit the reduced regional rate of income tax (a reduction not exceeding 4\%) with respect to some groups of taxpayers.

Federal taxes are: value-added tax (VAT), excise tax (on alcohol, tobacco, oil and oil-based products), corporate income tax (basic rate $35 \%-11 \%$ to the central budget, $19 \%$ to a regional budget and 5\% to municipal or district budgets), securities transaction tax, customs duty and customs charges, natural resources tax, charge for restoration of natural resources (for exploiting and polluting the natural environment), water tax, personal income tax, road user tax, inheritance and gift tax, tax on purchase of transport means and production of fuels, charge for using the words „Russia” and „Russian Federation”, fee for licence and permission to produce and trade in alcoholic beverages, tax on gambling, and social insurance contributions (unified social tax).

Local taxes are: individual property tax (2\%), land tax, registration fees for setting up a business, tax on industrial plants in health-resort areas (protected 
regions), tourist fee, charge for retail trade permit, fee for trade in alcoholic beverages (legal persons: 50 times of the minimum salary, natural persons: 25 times of the minimum salary), targeted district charges for maintaining the police, public goods and education, tax on advertising (5\% of the value of an advertisement), charges on selling cars, information technology equipment and computers, licensing fee for the right to organise auctions and lotteries, parking fee, charge for the right to use local symbols (e.g. in Moscow 12.5 times of the minimum salary every year), fee for hippodrome races, charge for stock-market operations, charge for shooting movies, charge for participation in horse races, fee for cleaning building sites, tax on dogs (except for working dogs), charge on foreign exchange operations, fee for residency registration, charge on winnings in games and lotteries, fee for setting up a gambling business (at least 205 times of the minimum salary), charge on winnings in sports competitions, and charge on persons participating in games of chance. ${ }^{8}$

Regional taxes are: corporate property tax, forest tax, tax on total revenue, educational fee.

The Ministry of Taxation is responsible for calculating and collecting taxes. It cooperates with the Ministry of Finance, responsible for revenue of the state budget, and with the Federal Agency on Economic and Tax Crimes at the Ministry of Interior. The Agency took over the responsibilities of the Tax Police on 1 July 2003 and was granted wide powers with respect to revealing tax frauds. In the recent years the Tax Police and the Agency on Economic and Tax Crimes have intensified their actions against major financial oligarchs who were charged with tax offences on a huge scale and with substantial diminishing of the state revenue. However, it is true that until recently both natural and legal persons in Russia were persistent in tax evasion. This encouraged treating tax obligations as a mere formality, not enforced by the state. Nevertheless, it seems that the authorities are determined to change this attitude and to reduce the problem of tax evasion considerably.

Both personal income tax and corporate income tax are particularly important for the state budget. The Tax Code of the Russian Federation (Part II) introduced a flat personal income tax. Since 1 January 2001 personal income tax has generally been reduced to $13 \%$. The consequences of the reduction turned out to be astonishingly favourable to the budget, ${ }^{9}$ with annual budget revenue growing by $50 \%$ every year since $2001 .^{10}$

8 www.coneseco.ru/eng/abc/tax/adm2_1.html (22 January 2002), also: G. D. Czernikow, Nałogi, Moskwa, Finanse i statistika, 1999, pp. 39-40.

9 S. Synelnikow-Muryliew, S. Batkibiekow, P. Kadocznikow, D. Niekipiełow, Ocienka rezultatow reformy podochodnogo nałoga w Rossijskoj Fiedieracii [in:] „Woprosy Ekonomiki” 2002, No. 6, pp. 61-64.

10 „Argumenty i Fakty”, 23 April 2003. Interview with G.I Bukayev, the Minister of Taxes and Fees of the Russian Federation, p. 2. 
In some cases, higher rates of personal income tax are applied. The highest rate of $35 \%$ applies mostly to specific income, i.e. winnings and prizes received in competitions and games, or paid by organisers of lotteries and other gambling games (including gaming machines).

Since 1 January 2002 the basic rate of corporate income tax, corresponding to the Polish corporate income tax, has been reduced from $35 \%$ to $24 \%$. The revenue of the state from this tax is divided among the budget tiers: $76 \%$ goes to the federal budget, up to $16 \%$ (but not less than $12 \%$ ) goes to the regional budget, and $2 \%$ to the local budget. The tax covers income of Russian legal persons earned in Russia and abroad, as well as income of foreign legal persons generated in the territory of Russia. ${ }^{11}$

Another tax collected in Russia is related to payment of remunerations. Part II of the Tax Code introduced the so-called unified social tax. This tax is calculated according to the rates declining from $35.6 \%$ to $2 \%$ with an increase in the total sum of remuneration of an employee, and paid by employer. Since the beginning of 2002, social tax paid to the federal budget has been reduced by the sum of the mandatory pension insurance. Remunerations of foreigners who are temporarily residing and employed in Russia are exempt from this insurance. The radical changes in the Russian tax system implemented in 2000 and 2001 aimed also at reducing burdens from earnings-related contributions.

Table 2. Social tax rates structure before and after reform

\begin{tabular}{||c|c|c|c|c||}
\hline & \multicolumn{2}{|c|}{ Before reform (2000) } & \multicolumn{2}{c|}{ After reform (2001) } \\
\hline Legal incidence & Income range & Marginal rate & Income range & Marginal rate \\
\hline Employee & All & 1 & All & 0 \\
\hline Employer & All & 38,5 & Below 100000 & 35,6 \\
\hline & & & $100000-300000$ & 20 \\
\hline & & & $300000-600000$ & 10 \\
\hline & & & Above 600000 & 5 (from 2002:2) \\
\hline
\end{tabular}

A. IVANOVA, M. KEEN AND A. KLEMM, The Russian 'flat tax' reform, Economic Policy July 2005 , The Institute For Fiscal Studies, Great Britain 2005.

Sale of goods and services in Russia and import of goods to Russia are subject to value-added tax (VAT; Russian: NDS, short for Natog na Dobawliennuju Stoimost). This tax concerns sellers of goods and services and importers of goods. The basic rate of VAT is $18 \%$. There is a group of goods and services covered by the reduced

11 A. Wasiliewa, E. Gurwicz, W. Subbotin. Ekonomiczieskij .op. cit. p. 49 and the following. 
rate of $10 \%$, as well as goods and services exempt from the tax (zero rate). In the tax structure (without charges and fees) VAT accounts for $36.5 \%$ of total taxes. After 2008 , the government intends to reduce the basic rate of VAT even to $10 \% .^{12}$

Another tax, excise, is charged on the sale of particular consumer goods, such as: spirit beverages, wine, beer, tobacco, cars, fuels, engine lubricants, and natural gas. Excise tax is paid at selling goods manufactured in the territory of Russia, at importing some kinds of goods, at making in-kind contributions with such goods to the initial capital of a company, using them for the producer's own needs, and in other similar situations. If producers use goods subject to excise as raw materials for manufacturing other excise goods, they can recover the tax paid at purchasing these goods, having fulfilled certain conditions. Excise tax is usually paid by manufacturers. Excise on imported goods is charged and paid together with customs charges. Excise stamps must be affixed to some goods subject to excise, such as beverages, alcohol and tobacco. The rates for all excise goods, except for natural gas, are expressed as a sum in ruble for a given unit of measurement, for example excise on 1 litre of alcohol equals 16.2 RUB, on 1 litre of beer: 4.60 RUB, and on 1 tonne of petrol: 2190 RUB (about 100 USD). ${ }^{13}$

Transport tax is a new tax, introduced on 1 January 2003, levied by regional governments. The sum of this tax is usually dependent on the engine capacity of a vehicle. Rates of the tax are determined by regional authorities, within the limits set by federal laws.

Taxes, customs duties and other charges paid to the budget are imposed on the basis of legal acts and can be changed only in this manner.

Representative agencies and branches of foreign enterprises operating in Russia are subject to taxation under the same rules as Russian companies. Establishing the tax base, expenses born by foreign enterprises can be deducted from their income in accordance with the same rules as those binding for Russian companies. ${ }^{14}$

All entities with an organisational unit in the territory of Russia are subject to the tax liability. This can be a branch, a subsidiary, a representative office, an agency or any other structure, adopted by a foreign company to conduct business. Foreign entities which conduct business through an agent are also regarded as having a permanent structure in the territory of Russia. An agent may be a Russian natural or legal person that represents the interest of a foreign entity on the basis of a contract, acts on its behalf, and is authorised to conclude and negotiate agreements on behalf of the foreign enterprise.

\footnotetext{
12 A speech by Dmitry Medvedev, Krasnoyarsk. Economic forum. 15 February 2008.

http://news.yandex.ru/yandsearch?.gazeta-unp.ru/\%26id\%3D6973

13 O.Wrubliewskaja, M. Romanowskij, Biudżietnaja sistiema Rossijskoj Fiedieracii, Moscow 2003, p. 162.

14 The part on taxes was prepared on the basis of: Rosyjska Federacja, Unido, Warsaw 2003, pp. 89-98.
} 


\section{Evaluation of changes in the tax system in Russia after 2000}

Analysing the outcomes of the tax reform in Russia in the few recent years, we should note that the economic situation is constantly improving, as a result of some other factors than transformation of the economy. This situation is favourably affecting the condition of public finance. The most important stimuli to growth of the Russian economy are factors of both external and internal character: a significant growth in prices of energy resources on international markets, economic growth, structural reforms implemented in the economy, and good financial condition of a considerable number of economic entities.

The favourable situation in foreign trade and in the economy is conducive to the stabilization of public finance, makes the realization of budget revenue possible, and results in a surplus of budget revenue over expenditure. The problem of the Russian Federation government is the rational use of the strong flow of ,petrodollars," as well as securing against a decline in prices of energy resources (creating financial reserves), and, at the same time, curbing the inflationary pressure triggered by this inflow of resources from exports.

To sum up, it should be stated that the major issue faced by Russia at the moment is taking advantage of a boom on the resources markets and financing intensive factors of the internal development with acquired funds. Russia does have money and must decide how to allocate it: for consumption or investment in economy. Currently, the majority of money is spent on consumption and the minor part on investment. This is not a good policy, as it does not lead to a permanent upward trend, based on internal factors of economic growth.

On 1 January 2004 the Government of Russia established the Stabilization Fund. Its aim is to secure the balance of the state budget in a situation of a considerable reduction in prices of energy resources (oil and gas) dominant in the Russian exports. The Fund supports the stabilization of the economic development of the state, is one of the basic instruments of absorbing the excessive liquidity, lessens inflationary pressure, reduces the dependence of the Russian economy on unwelcome changes of prices on foreign markets and volatility of earnings from energy resources export on the level of foreign exchange reserves of the state. The Fund's resources are generated from imposing additional customs duty on exported oil and taxes on the output of natural resources when oil price is higher than the established base price, that is 27 USD per barrel (Urals type), as a part of the state budget.

In December 2007 the Fund had on its bank account 157.38 billion USD, ${ }^{15}$ which constituted about $11.7 \%$ of GDP. 
On 1 January 2008 the Stabilization Fund was split into two parts: the Reserve Fund managing the resources of 56.9 billion USD and the National Welfare Fund having at its disposal 125.0 billion USD. ${ }^{16}$

The statistics of the Bank of Russia and the Ministry of Finance of the Russian Federation present the budget of the Federation in three forms: as the consolidated budget, the federal budget and the consolidated budget of entities of the Russian Federation. ${ }^{17}$ The consolidated budget system in Russia encompasses the following units: the federal budget, budgets of republics, budgets of territories, budgets of provinces, the budget of Moscow and the budget of Saint Petersburg, budgets of autonomous districts, municipal budgets of cities, and budgets of rural regions.

After 2000, following the reform of the tax system and other circumstances favourable to Russia (including an increase in prices of energy resources), the situation of the Russian budget has considerably improved. Since 2000 there has been a surplus of budget revenue over expenditure. In 2004 the budget surplus accounted for more than 4\%, and in 2005 for almost 8\% of GDP. In 2006 the surplus of revenue over expenditure of the federal budget exceeded $8 \%$ of GDP.

Figure 2. Ratio (deficit - 1995) - proficit of the consolidated budget of Russia to GDP (in \%)

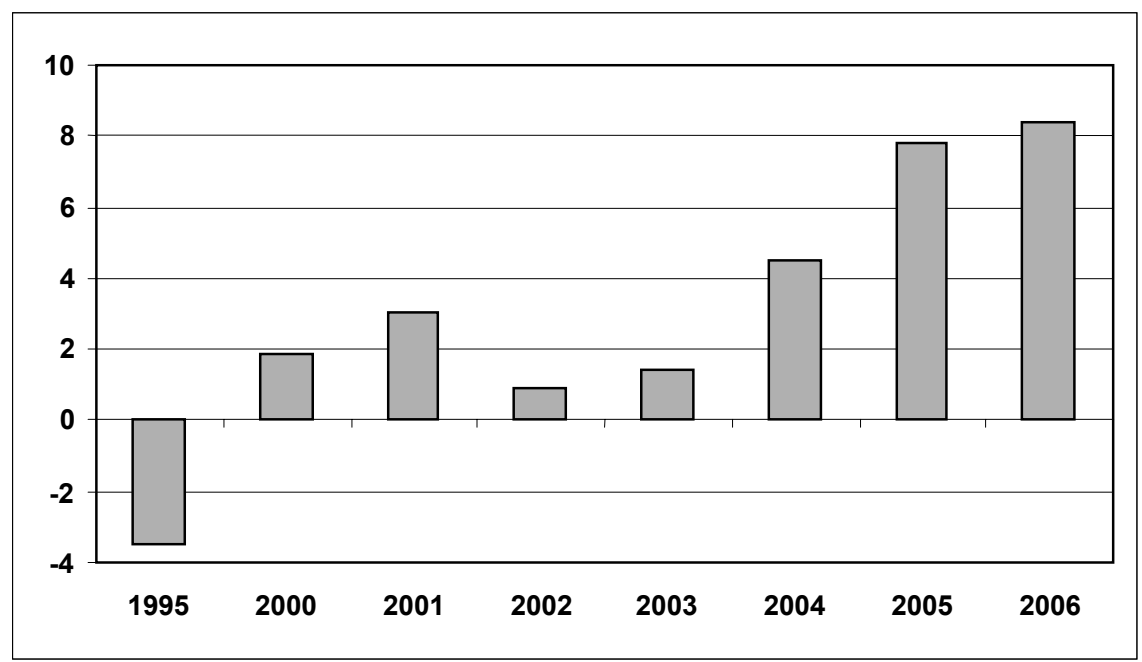

Source: Data of the Russian statistical office (Rosstat). Moscow, 2007.

\footnotetext{
16 The Ministry of Finance of the Russian Federation http://www1.minfin.ru/ru/reservefund/statistics/volume/index. php?id4=5796 data as at 12 February 2008.

17 Biulletien bankowskoj statistiki. CBRF, Moscow 2002, No. 10 (113), p. 8.
} 
In 2007 the federal budget revenue equalled 7,779.1 billion RUB and expenditure 5,983.0 billion RUB. The surplus of the federal budget was 1796.1 billion RUB (about 50 billion EUR) against the planned sum of 912 billion RUB. ${ }^{18}$ The consolidated budget revenue in 2007 equalled 13,250.7 billion RUB, expenditure: $11,245.8$ billion, and the surplus of the consolidated budget of 2,004.9 billion RUB accounted for $6.1 \%$ of the GDP in Russia. Thus, a surplus of budget revenue over expenditure occurs both at the level of the Federation budget and of the consolidated budget (the sum of all other budgets) of Russia.

In 2007 the detailed structure of revenue and expenditure of the consolidated budget was as follows:

Table 3. The consolidated budget of the Russian Federation in $2007^{1}$

\begin{tabular}{||l|c|c|}
\hline \multicolumn{1}{|c|}{ Specification } & Billion RUB & \% of GDP \\
\hline I. Total revenue of consolidated budget & 13250.7 & 40.2 \\
\hline of which: & & \\
\hline 1. Corporate income tax & 2172.0 & 6.6 \\
\hline 2. Personal income tax & 1266.6 & 3.8 \\
\hline 3. Unified social tax & 656.7 & 2.0 \\
\hline 4. Value-added tax (VAT): & & \\
\hline - on goods (services) manufactured and sold in the Russian Federation & 1390.6 & 4.2 \\
\hline - on goods brought into the Russian Federation & 871.1 & 2.6 \\
\hline 5. Excise on goods: & & \\
\hline - manufactured in the Russian Federation & 288.2 & 0.9 \\
\hline - brought into the Russian Federation & 26.2 & 0.1 \\
\hline 6. Total income tax & 141.8 & 0.4 \\
\hline 7. Property tax & 411.2 & 1.2 \\
\hline $\begin{array}{l}\text { 8. Taxes, one-off charges and regular charges for exploitation } \\
\text { of natural resources }\end{array}$ & 1235.1 & 3.7 \\
\hline 9. Revenue from economic activity abroad & 2408.3 & 7.3 \\
\hline \begin{tabular}{l} 
10. Revenue from use of the state or municipal property \\
\hline 11. Charges for occasional use of natural resources
\end{tabular} & 525.0 & 1.6 \\
\hline 12. Tax on gifts & 82.4 & 0.2 \\
\hline
\end{tabular}

18 Resources of the website: http://www.regnum.ru/news/758243.html (downloaded on 13 January 2007). 
Marian Żukowski, Helena Żukowska

\begin{tabular}{|l|c|c|}
\hline $\begin{array}{l}\text { 13. Taxes on revenue from conducting business or from other gainful } \\
\text { activity }\end{array}$ & 112.3 & 0.3 \\
\hline & & \\
\hline II. Total expenditure of consolidated budget & 11245.8 & 34.1 \\
\hline of which: & & \\
\hline 1. General state expenditure & 1166.7 & 3.5 \\
\hline - of which: service of state and municipal debt & 175.2 & 0.5 \\
\hline 2. Defence & 834.0 & 2.5 \\
\hline 3. National security and administration of justice & 864.4 & 2.6 \\
\hline 4. National economy & 1560.4 & 4.7 \\
\hline of which: & & \\
\hline - fuel and energy industry & 33.5 & 0.1 \\
\hline - agriculture and fisheries & 147.0 & 0.4 \\
\hline - transport & 580.7 & 1.8 \\
\hline - communication and information technology & 36.8 & 0.1 \\
\hline - basic scientific research & 62.9 & 0.2 \\
\hline - other expenses of national economy & 589.9 & 1.8 \\
\hline 5. Public utility and housing expenditure & 1101.4 & 3.3 \\
\hline 6. Social and cultural expenditure & 5692.3 & 17.3 \\
\hline Surplus of consolidated budget & 2004.9 & 6.1 \\
\hline
\end{tabular}

${ }^{1}$ The data include budgets of the state non-budget funds.

Source: Rossija wcifrach 2008, Kratkij statisticzeskij sbornik, Federalnaja Stużba Gosudarstwiennoj Statistiki, (Rosstat), Moscow 2008.

The surplus of revenue over expenditure (or budget proficit), occurring in the consolidated and federal budget of Russia for several years, triggers mixed reactions. Some regard it as beneficial, but experts increasingly point to the fact that a substantial and long-lasting surplus of revenue over expenditure hampers economic growth. Therefore, there is an intention to reduce considerably the scale of the budget surplus in the plans for the Russian budget for the years 2008-2010. Nevertheless, it can be assumed that the budget proficit will still be fuelled by such factors as: a growth of industrial production and improved financial condition of enterprises, situation in the international trade - favourable for Russia, and growing prices of Russian export commodities, economical financing of budgetary expenditure in fear of pushing up 
inflation, and controlling the financial policy with respect to realization of budget revenue and an increase in tax collection. ${ }^{19}$

\section{Necessary changes in the tax system of Russia}

A picture of the tax system in Russia, illustrated for instance by sources of state budget revenue, reveals the need for further reforms. The tax system after the reform is still rather complicated, there is a large variety of taxes and charges, serious problems with collection of taxes, and corruption in tax offices.

In the following years, the goals of the tax system reform in Russia should be:

1) improvements in the tax law aimed at its simplification, stabilization of tax rules, reduction in tax burdens for honest taxpayers,

2) elimination of contradictions between the tax law and the civil code,

3) elimination of opportunities for tax evasion,

4) enhancement of the efficiency of tax administration.

Further reductions in tax rates are planned. According to experts, ${ }^{20}$ VAT should be cut down to $15 \%$, while social insurance contributions to $30 \%$ and ultimately to $25 \%$. Advocates of this approach argue that, in accordance with the interpretation of Laffer curve, reductions of tax rates in Russia in recent years have always resulted in the increased budget revenue.

There are plans to introduce new solutions soon with respect to the taxation of SMEs in Russia. The basic rate of income tax shall be $6 \%$ of revenue tax or $15 \%$ of income tax after deduction of revenue-earning costs. ${ }^{21}$ Moreover, the government intends to launch a simplified taxation system for micro-enterprises starting their business activity. Only when these changes are introduced, the tax system reform can be deemed completed. ${ }^{22}$ Nevertheless, the proper implementation of the budgetary policy is a significant factor in achieving the pursued goals of the public finance reform. The primary task of the budgetary policy within the framework of the economic policy is the financial security of the discharge of public liabilities by the state. $^{23}$

19 W. Mau, Ekonomiczieskaja polityka 2007 goda: uspiechi i riski. In: Woprosy Ekonomiki, No. 2/2008, pp. 5-8.

20 The opinion of Arkadiy Dvorkovich, the Minister of Economic Development and Trade of the Russian Federation, „FinNews”, 5 November 2002.

21 A speech by Gennady I. Bukayev, the Minister of Taxes and Fees of the Russian Federation, at a meeting of the Heads of Tax Administration of the Baltic region, 26-27 October 2002.

22 Based on: M. Żukowski, H. Żukowska, Reforma systemu podatkowego w Federacji Rosyjskiej, Lublin 2003, manuscript, pp. 14-19.

23 G. Kołpakowa Biudżietnaja sistiema Rossijskoj Fiedieracii. Finanse, dienieżnoje obraszczenije, kriedit, Moscow 2002, pp. 125-150. 
The effectiveness of the budgetary policy in Russia has been extremely low in recent years, which is shown by the following phenomena:

- persistent failure to discharge its liabilities by the state,

- the weakness of the tax system which is unable to perform either its fiscal or regulatory functions efficiently (which is proved by the mass tax evasion),

- the ,expensive” state, as a result of ineffective actions of the administration which aims at seizing maximum sums from the right of redistribution of economic resources, which in consequence leads to unequal competitive conditions and makes the protection of ownership rights impossible.

Thus, it can be argued that the budgetary policy in Russia is inefficient and that maintaining such a condition is one of the major obstacles to the steady economic growth. Apart from the implemented tax system reform which is improving the situation of the state budget, other key steps in the budgetary policy should include:

1) achieving a balance between liabilities of the state and possibilities of their discharge;

2) discharging liabilities of the state to lenders and creditors, and settlements with debtors;

3) calculating the liabilities taken on by the state and associated budget expenditure;

4) auditing the performance of budgets at all levels.

The government should aim at covering the liabilities of the state to various social groups and at reducing the foreign debt. A negative phenomenon is a growing pressure of regions and other "beneficiaries” seeking increased donations from the central budget. The key objective of the changes in the pursued budgetary policy should be the establishment of permanent institutional mechanisms encouraging regional and local authorities to carry out structural reforms of the public finance system. The achievement of this goal would facilitate the discharge of the government's liabilities and would guarantee equal access of citizens to basic social services and benefits. The factors supporting the attainment of these goals include:

a) modernisation of the economy; ${ }^{24}$

b) decentralisation of the budget system, with simultaneous transfer of the liabilities of the national character to the federal level, and providing appropriate sources for financing the federal needs; 
b) radical changes in revenue and expenditure of local budgets, assuming a departure from the distribution of tax revenue between budgets of particular tiers, and preferring the rule: ,one budget - one tax”;

c) co-financing ,priority" investments also with funds from regional budgets.

However, we can doubt whether the attainment of these goals is possible in a short period of time. Without passing the necessary legislation, conflicts and „rough and tumble" between the central budget and regional budgets will not be terminated. Taking into consideration the implementation of the adopted plans in the years to come, the government of Russia should introduce the following changes: ${ }^{25}$

a) adopt the minimum flat rate of personal income tax (12\%) and at the same time raise the tax-free minimum of income and abolish the majority of tax deductions;

b) establish one social tax, reduce the rates and set up the upper ceiling of taxable income;

c) abolish turnover tax and compensate for the reduced income with the introduction of the local tax mentioned above, and with an increase in excise duty on oil products;

d) abolish the majority of deductions in VAT;

e) change the rules of imposing excise tax on alcoholic beverages and oil products in order to transfer the maximum amount of the tax burden into the consumption area;

f) replace real estate tax with property tax and land tax,

g) undertake steps aimed at improvements in the performance of administration and tax offices.

\section{Conclusions}

Hence, all reforms, including tax ones, should contribute to the transformation of the state into a productive tool which serves the society and fulfils its responsibilities efficiently for the benefit of citizens, institutions and economic entities.

To sum up, the Russian economy and the tax system should undergo further changes, for a number of reasons. Firstly, due to their large-scale incompatibility with the tax systems of developed countries. Secondly, owing to natural changes occurring in all areas of the business life and the tax system, and the more so in the

E. Strojew, Ekonomiczieskije reformy w Rossii: wzgliad w buduszczie, „Woprosy Ekonomiki”, 2001/6, pp. 4-12. 
realities of Russia. These changes should aim at ordering the tax law, simplifying the tax system, limiting the range of taxation, and thus improving the situation of enterprises and, through tightening up the tax system, restricting the scope of the informal economy. ${ }^{26}$ 


\section{Streszczenie}

Niniejszy artykuł przedstawia reformę rosyjskiego systemu podatkowego. Zawarto w nim opis struktury dochodów podatkowych zasilających skonsolidowany budżet Federacji Rosyjskiej, jak również zarys całego systemu podatkowego wraz ze stawkami podatkowymi. Autorzy szczegółowo analizuja podstawowe rodzaje podatków oraz przesłanki reform rosyjskiego systemu podatkowego. 